\title{
СЛДЧІ (РОЗШУКОВІ) ДІї ЯК СКЛАДОВА ДОСУДОВОГО РОЗСЛІДУВАННЯ
}

\author{
САЛМАНОВ Олексій Валерійович - викладач кафедри кримінального \\ процесу та організації досудового слідства Харківського національного \\ університету внутрішніх справ \\ https://orcid.org/0000-0001-9421-5085 \\ УДК 343.14 \\ DOI 10.32782/NP.2020.4.16
}

У статті охарактеризовано наукові та нормативно-правові джерела, шо регламентують здійснення досудового розслідування взагалі та слідиих (розшукових) дій зокрема. 3'ясовано, що слідчі (розшукові) дї є основним засобом доказування, інструментом пізнавальної діяльності з розслідування кримінальних правопорушень. Встановлено, що законодавче визначення слідчої (розшукової) дї̈ є недосконалим $і$ не повністю відображає ï сутність як засобу отримання доказів під час здійснення досудового розслідування. Проаналізовано наукові підходи до визначення основних ознак і поняття слідчих (розшукових) дій у баховій літературі й на їх основі запропоновано більш деталізоване тлумачення терміну «слідча (розшукова) дія». Встановлено, що основними рисами слідчой (розшукової) діӥ є чітка регламентація підстав, порядку та уповноважених ї проводити суб'єктів нормами кримінального процесуального законодавства; спрямованість на пошук, отримання та перевірку доказів $i$ відомостей про них. Слідчу (розшукову) дію визначено як сукупність пізнавальних $і$ пошукових дій, шзо здійснюються уповноваженими суб'єктами на підставах та в порядку, визначених кримінальним прочесуальним законом, з метою бормування доказової бази.

Ключові слова: слідча (розшукова) дія, негласна слідиа (розшукова) дія, досудове розслідування, кримінальне провадження, кримінальне процесуальне законодавство.

\section{Постановка проблеми}

Важливим способом збирання та перевірки доказів у кримінальному провадженні є слідчі (розшукові) дії. Від того, наскільки точно будуть дотримані вимоги кримінального процесуального закону та криміналістичні рекомендації під час їх проведення, залежить можливість усебічного, повного й неупередженого встановлення обставин, які мають значення для кримінального провадження та відповідно виконання його завдань. Саме тому законодавець приділяє значну увагу регламентації цього процесуального інституту [1, с. 135]. Доцільність же більш поглибленого вивчення питань, пов'язаних із слідчими (розшуковими) діями, як слушно відзначає О.В. Іванцова, посилюється тим, що за своєю правовою суттю вони містять найбільш імовірні ризики протизаконного та необгрунтованого обмеження прав і свобод людини в кримінальному провадженні на стадії досудового розслідування, а під час їх проведення мають бути обов'язково дотримані як загальні засади кримінального провадження, так i встановлена Кримінальним процесуальним кодексом України (далі - КПК України) відповідна процесуальна форма, порушення якої впливає на ефективність досягнення завдань кримінального провадження [2, с. 97]. У зв'язку з цим актуальним $є$ питання про визначення ознак і поняття слідчих (розшукових) дій як складової досудового розслідування. 


\section{Кримінальне право, кримінальний процес та криміналістика}

\section{Аналіз останніх досліджень}

Питання про доказування в кримінальному провадженні та слідчі (розшукові) дії як засіб такого доказування зокрема неодноразово досліджували у своїх працях такі вчені, як: О.Я. Баєв, Р.С. Бєлкін, В.I. Галаган, В.Г. Гончаренко, А.Я. Дубинський, А.П. Аазарєв, О.М. Ларін, І.М. Аузгін, Б.С. Аук'янчиков, С.Д. Аук'янчиков, С.Б. Мєлєшев, М.М. Михеєнко, В.Т. Нор, О.А. Осауленко, М.А. Погорецький, Д.Б. Сергєєва, О.С. Старенький, С.М. Стахівський, I.I. Цилюрик, С.А. Шейфер, В.П. Шибіко, А.О. Шульга, М.Є. Шумило й інші. Проте, незважаючи на вагомий внесок указаних науковців у вирішенні окресленої проблематики, чимало питань і досі залишається дискусійними. Зокрема, відсутня узгодженість наукових позицій щодо визначення поняття та ознак слідчих (розшукових) дій як складової досудового розслідування. Тому метою представленого дослідження 6 здійснення аналізу наукових поглядів стосовно тлумачення терміну «слідча (розшукова) дія», виокремлення властивостей слідчих (розшукових) дій, з'ясування їх значення в досудовому розслідуванні та форму^ювання авторського визначення поняття слідчих (розшукових) дій.

\section{Виклад основного матеріалу}

Як зазначають Б.С. Аук'янчиков, Є.Д. Аук'янчиков, основним інструментом пізнавальної діяльності з розкриття та розслідування злочинів е слідчі (розшукові) дії. Дослідженню цього інституту кримінального процесуального права науковці приділяють увагу на всіх етапах розвитку кримінального процесуального законодавства [3, с. 69]. А.О. Шульга уточнює, що слідчі (розшукові) та негласні слідчі (розшукові) дії це не тільки засоби (інструментарій) встановлення обставин кримінального правопорушення, але і засоби забезпечення кримінального провадження у цілому [4, с. 160].

B.I. Галаган правильно підмічає, що кожна слідча дія є дією процесуальною, яка не лише зазначається, але й детально врегульовується у чинному КПК. Разом з тим, при віднесенні процесуальних дій до слідчих залишилися суперечливі і невизначені положення [5, с. 1]. Саме тому вважаємо за необхідне розпочати висвітлення вказаного питання зі з'ясування законодавчого трактування слідчих (розшукових) дій і їх ролі в кримінальному провадженні.

У ч. 1 ст. 223 КПК України закріплено, що слідчі (розшукові) дії 6 діями, спрямованими на отримання (збирання) доказів або перевірку вже отриманих доказів у конкретному кримінальному провадженні. При цьому законодавець зазначає, що підставами для проведення слідчої (розшукової) дії є наявність достатніх відомостей, що вказують на можливість досягнення ії мети [6]. 3 наведеного помітно, що слідчі (розшукові) дії $е$ нічим іншим як засобом доказування. Останне згідно з ч. 2 ст. 91 КПК України полягає у збиранні, перевірці та оцінці доказів $з$ метою встановлення обставин, що мають значення для кримінального провадження [6]. Більше того, в ст. 93 зазначеного нормативно-правового акта вказується, що збирання доказів здійснюється сторонами кримінального провадження, потерпілим, представником юридичної особи, щодо якої здійснюється провадження, у порядку, передбаченому цим Кодексом. При цьому сторона обвинувачення здійснює збирання доказів шляхом проведення слідчих (розшукових) дій та негласних слідчих (розшукових) дій, витребування та отримання від органів державної влади, органів місцевого самоврядування, підприємств, установ та організацій, службових та фізичних осіб речей, документів, відомостей, висновків експертів, висновків ревізій та актів перевірок, проведення інших процесуальних дій, передбачених КПК України, а сторона захисту, потерпілий, представник юридичної особи, щодо якої здійснюється провадження, - шляхом витребування та отримання від органів державної влади, органів місцевого самоврядування, підприємств, установ, організацій, службових та фізичних осіб речей, копій документів, відомостей, висновків експертів, висновків ревізій, актів перевірок; ініціювання проведення слідчих (розшукових) дій, негласних слідчих (розшукових) дій та інших процесуальних дій, а також шляхом здійснення інших дій, які здатні забезпечити подання суду належних і допустимих 
доказів [6]. Тобто сторона обвинувачення з метою доказування з урахуванням конкретних обставин кримінального провадження використовує такий засіб збирання доказів, як проведення слідчих (розшукових), у тому числі негласних, дій. Що ж стосується сторони захисту, потерпілого, представника юридичної особи, щодо якої здійснюється провадження, то вони не є суб'єктами проведення слідчих (розшукових) дій. Проте вони вправі ініціювати їх проведення шляхом подання слідчому, прокурору відповідних клопотань, які розглядаються в порядку, передбаченому ст. 220 КПК України [6].

На думку Д.Б. Сергєєвої та О.С. Старенького, законодавче визнання слідчих (розшукових) дій є недосконалим і таким, що не повною мірою відповідає сутності слідчих (розшукових) дій як засобам отримання доказів у кримінальних провадженнях [7, с. 82]. 3 наведеним твердженням погоджуємося, оскільки дійсно запропонована законодавцем дефініція не відображає ані розшукового характеру таких дій, ані суб'єктів і процедури їх проведення. У зв'язку з цим вбачається за необхідне ретельно проаналізувати наукові підходи до визначення основних ознак і поняття слідчих (розшукових) дій у фаховій літературі й на їх основі запропонувати більш деталізоване трактування терміну «слідча (розшукова) дія».

У кримінальній процесуальній правовій науці сформувалося два підходи до визначення поняття слідчих (розшукових) дій (слідчих дій за Кримінально-процесуальним кодексом України від 1960 року) - у широкому та вузькому розуміннях. Представники першого підходу відносять до таких дій будьякі процесуальні дії слідчого, як спосіб здійснення норм кримінального процесуального законодавства $[8$, с. $58 ; 5$, с. $70 ; 7$, с. 82-83], а другого - визначають слідчі (розшукові) дії як самостійний елемент регламентованої кримінальним процесуальним законом діяльності слідчого з отримання, дослідження й оцінки доказів [9, с. 234]; передбачені процесуальним кодексом заходи, які застосовуються компетентними особами для збирання, дослідження, оцінки та використання доказів (інформації) під час конкретного кримінального провадження [10, с. 482].
I.I. Цилюрик, досліджуючи гарантії прав, свобод та законних інтересів учасників кримінального провадження під час проведення слідчих (розшукових) дій, сформулювала авторське визначення поняття «слідчі (розшукові) дії» у вузькому розумінні, а саме - це передбачена КПК України процесуальна діяльність, яка є основним способом збирання доказів у кримінальному провадженні, здійснювана уповноваженими на те законом службовими особами і безпосередньо спрямована на виявлення, отримання, закріплення і перевірку (оцінку) відомостей, що відносяться до справи. Характеризуються слідчі (розшукові) дії сукупністю пошукових, пізнавальних і посвідчувальних процесуальних процедур, визначеним колом учасників, детальною регламентацією всього порядку їх проведення, оформлення, а також забезпеченістю опосередком легітимного процесуального примусу [11, c. 5]. Також досить розгорнуте визначення слідчих (розшукових) дій запропонував В.В. Вапнярчук, а саме - це регламентовані кримінальним процесуальним законом дії, спрямовані на формування або дослідження доказової основи правової позиції певного суб'єкта доказування, які суттєво зачіпають права і законні інтереси людини, здійснюються компетентною посадовою особою і пов'язані $з$ можливістю застосування заходів державного процесуального примусу у забезпеченні їх проведення або безпосередньо під час проведення [12, с. 74].

Проте, на превеликий жаль, єдиного підходу до використання термінології для визначення поняття слідчих (розшукових) дій немає. Тому для правильного визначення поняття слідчих (розшукових) дій як засобів отримання доказів у кримінальних провадженнях Д.Б. Сергєєва й О.С. Старенький пропонують визначити іх сутнісні ознаки. Зокрема, такими, на їх думку, є: вони є заходами, тобто діями або засобами для досягнення чогось, що мають активний діяльнісний характер; передбачені та регламентовані нормами КПК України; є частиною процесуальних дій, що мають пошуково-пізнавальний та посвідчувальний характер; можуть здійснюватися лише уповноваженими суб'єктами [7, с. 84-85]. При 


\section{Кримінальне право, кримінальний процес та криміналістика}

цьому під слідчими (розшуковими) діями вчені пропонують розуміти заходи, що складаються 3 сукупності пошуково-пізнавальних, розшукових та посвідчувальних прийомів, проводяться спеціально уповноваженим кримінальним процесуальним законом суб'єктом у визначеному для кожного з них порядку з метою виявлення й закріплення фактичних даних і відомостей про їх джерела для отримання доказів у кримінальних провадженнях [7, с. 87].

А.Я. Дубинський серед ознак слідчих (розшукових) дій пропонує виокремлювати те, що вони здійснюються відповідно до визначених процедурних вимог [13, с. 215]. Визначаючи поняття слідчих (розшукових) дій, окремі з учених також акцентують увагу на таких іiі рисах, як забезпечення державним примусом і поєднання прийомів i операцій задля досягнення єдиної цілі - виявлення, фіксації та перевірки фактичних даних, які мають значення доказів у кримінальному провадженні [14, с. 106]; комплексний характер пізнавальних і засвідчувальних операцій, що відповідають особливостям певних слідів і пристосовані для ефективного відшукання, сприйняття та закріплення доказової інформації, що в них міститься [15, с. 23-24]. С.М. Стахівський як важливу ознаку слідчої (розшукової) дії виокремлює силу процесуального примусу [16, с. 7]. М.А. Погорецький також відзначає, що однією 3 відмінних ознак слідчої (розшукової) дії є те, що їх здійснюють особи, які наділені владними повноваженнями примусового характеру [17, с. 392-393].

В.В. Вапнярчук зазначає, що в юридичній літературі виділяють низку особливостей слідчих (розшукових) дій, які дозволяють відмежувати їх від інших дій. Зокрема, серед них найбільш уживаними є регламентований кримінальним процесуальним законом порядок проведення; пізнавальна спрямованість; забезпечення державним примусом; суттєве зачіпання прав і законних інтересів людини, у зв'язку з чим деякі зі слідчих (розшукових) дій можуть бути проведені тільки на підставі рішення слідчого судді або прокурора [12, с. 73-74].

3 вищенаведеного помітно, що ознаки, які притаманні слідчим (розшуковим) діям, визначають їх сутність і значення в кримінальному провадженні. На нашу думку, основною рисою слідчих (розшукових) дій 6 те, що вони чітко регламентовані нормами кримінального процесуального законодавства, а значить, є процесуальними діями 3 визначеними законодавством підставами та порядком проведення. Однак варто зазначити, що вказані категорії - «слідча (розшукова) дія» та «процесуальна дія» - хоча й 6 взаємопов'язаними, але жодним чином не є тотожними, взаємозамінними поняттями. Процесуальні дії за своїм змістом є досить широким поняттям, яке включає в себе й слідчі (розшукові) дії. Тобто вони співвідносяться як загальне й окреме. Це означає, що слідча (розшукова) дія є різновидом процесуальних дій, а значить, їй притаманна така їх риса, як чітка регламентованість нормами кримінального процесуального законодавства підстав, порядку та уповноважених суб'єктів їх проведення. Зокрема, фактично підставою для проведення слідчих (розшукових) дій визнаються конкретні обставини, що зумовлюють необхідність проведення відповідної слідчої (розшукової) дії, а правовою підставою - наявність в уповноваженої особи повноважень на проведення слідчих (розшукових) дій у межах відповідного кримінального провадження та дотримання визначеного законом порядку прийняття рішення на проведення конкретної слідчої (розшукової) дії [2, с. 98]. Щодо порядку проведення слідчих (розшукових) дій, то законодавець його визначив залежно від конкретного різновиду такої дії.

Ще однією невід'ємною рисою, яка характеризує слідчі (розшукові) дії як складову досудового розслідування та визначає їх правову природу, є їх призначення. Останнє частково визначив законодавець, указавши мету проведення слідчих (розшукових) дій у ч. 1 ст. 223 КПК України. Мета проведення слідчої (розшукової) дії визначається iї спрямованістю на отримання (збирання) доказів або перевірку вже отриманих доказів у конкретному кримінальному провадженні [4, с. 161]. Разом з тим, як указує В.П. Сердюк, кожна зі слідчих дій є розшуковою, тому всі вони спрямовані на пошук доказу: деякі з них їх прямо закріплюють, а 
інші мають це своїм завданням, але виконуються вони офіційно і лише у рамках єдиного закону - КПК України [18, с. 258]. Тому, на його думку, термін «слідча (розшукова) дія» в повній мірі передає їі сутність і функціональне призначення. Тобто ототожнення законодавцем понять слідчих і розшукових дій слідчого свідчить про те, що слідчим діям притаманний активний пошуковий характер [19, с. 280].

Щодо значення слідчих (розшукових) дій у досудовому розслідуванні також вдалим убачається твердження А.П. Аазарєва. На його думку, слідчі (розшукові) дії 6 одним із основних інструментів зі встановлення обставин, які підлягають доказуванню у кримінальному провадженні. Це виражається в тому, що на підставі проведення названих дій слідчий повинен визначити межі предмета доказування з урахуванням норм матеріального права, встановити факт кримінального правопорушення, фактичні дані, відомості про факти та процесуально закріплені докази, що вказують на вину підозрюваного. Він повинен встановити обставини кримінального правопорушення, ступінь тяжкості його вчинення та/або підстави для звільнення від кримінальної відповідальності [20, с. 10]. Більше того, як зазначає науковець, кожна слідча (розшукова) дія містить у собі комплекс пізнавальних моментів, що забезпечується встановленням певних слідів та істини [21, с. 118].

\section{Висновки}

Отже, слідча (розшукова) дія є правовою категорією, яка виступає як основний інструмент доказування в кримінальному провадженні на стадії досудового розслідування. Їй притаманна ціла низка ознак, які визначають іiі правову природу. Зокрема, основними рисами слідчої (розшукової) дії як складової досудового розслідування, основними 3 яких 6 чітка регламентація підстав, порядку та уповноважених іiі проводити суб'єктів нормами кримінального процесуального законодавства; спрямованість на пошук, отримання та перевірку доказів і відомостей про них. Під слідчою (розшуковою) дією пропонуємо розуміти сукупність пізнавальних і пошукових дій, що здійснюються уповноваженими суб'єктами на підставах та в порядку, визначених кримінальним процесуальним законом, з метою формування доказової бази.

\section{Література}

1. Карпушин С.Ю. Повторні слідчі (розшукові) дії в кримінальному провадженні. Науковий вісник Міжнародного гуманітарного університету. Сер.: Юриспрудениія. 2015. № 17. Том 2. С. 135-138.

2. Іванцова О.В. Особливості проведення слідчих (розшукових) дій у ході розслідування злочинів у галузі цукрового виробництва. Актуальні проблеми вітчизняної юриспрудениій. 2017. № 2. Том 1. С. 97-101.

3. Аук'янчиков Б.С., Аук'янчиков С.Д. Слідчі (розшукові) дії, як засоби інформаційного забезпечення кримінального провадження. Інбормаиія і право. 2016. № 3 (18). C. $68-72$.

4. Шульга А.О. Невідкладність слідчих (розшукових) та негласних слідчих (розшукових) дій. Правовий часопис Донбасу. 2018. № 2 (63). С. 160-163.

5. Галаган B.I. Слідчі дії: проблеми визначення. Часопис Національного університету «Острозъка академія». Серія «Право». 2010. № 1. URL: https://j.oa.edu.ua/articles/2010/ n1/10hvidpv.pdf.

6. Кримінальний процесуальний кодекс України: закон України від 13.04.2012 № 4651-VI. Відомості Верховної Ради України. 2013. № 9-10. Стор. 474. Стаття 88.

7. Сергєєва Д.Б., Старенький О.С. Слідчі (розшукові) дії як засоби отримання доказів у кримінальних провадженнях щодо неповнолітніх: до визначення поняття. Biсник кримінального судочинства. 2017. № 1. C. 81-89.

8. Аузгин И.М. Расследование как процесс познания: учеб. пособ. М.: Высш. шк. МВД СССР, 1969. 178 с.

9. Белкин Р.С. Курс криминалистики: Частные криминалистические теории: в 3-х т. М.: Юристъ, 1997. Т. 2. 464 с.

10. Кримінальний процесуальний кодекс України: науково-практичний коментар; за заг. ред. професорів В.Г. Гончаренка, В.Т. Нора, М.Е. Шумила. К.: Юстініан, 2012. 1224 c. 


\section{Кримінальне право, кримінальний процес та криміналістика}

11. Цилюрик I.I. Гарантії прав, свобод та законних інтересів учасників кримінального провадження під час проведення слідчих (розшукових) дій: автореф. дис. ... канд. юрид. наук: спец. 12.00.09. Аьвів, 2020. 19 с.

12. Вапнярчук В.В. Поняття і система слідчих (розшукових) дій. Науковий вісник Херсонського державного університету. Серія Юридичні науки. 2018. Випуск 2. Том 2. С. 7377.

13. Дубинский А.Я. Производство предварительного расследования органами внутренних дел. Вибрані пращі. К.: Центр учбової літератури, 2014. С. 169-257.

14. Аук'янчиков С.Д., Аук'янчиков Б.С. Негласні слідчі (розшукові) дії - засоби процесуального доказування. Право украйни. 2014. № 10. С. 106-115.

15. Шейфер С.А. Следственные действия. Основания, процессуальный порядок и доказательственное значение. Самара:Самарский ун-т, 2004. 225 с.

16. Стахівський С.М. Слідчі дії як основні засоби збирання доказів: наук.-практ. посіб. К.: Атіка, 2009. 64 с.

17. Погорецький М.А. Функціональне призначення оперативно-розшукової діяльності у кримінальному процесі: монографія. Х.: Арсіс, АТД, 2007. 576 c.

18. Сердюк В.П. Слідчі (розшукові) дії у кримінальному провадженні України: процесуальні проблеми. Право і суспільство. 2017. № 1. Частина 2. С. 255-259.

19. Кіпрач I.C. Визначення поняття слідчих (розшукових) дій. Науковий вісник Наиіональної академії внутрішніх справ. 2013. № 2. C. 275-283.

20. Аазарєв А.П. Механізм проведення слідчих (розшукових) дій у кримінальному
The article describes the scientific and regulatory sources governing the implementation of pretrial investigation in general and investigative (investigative) actions in particular. It was found that investigative (search) actions are the main means of proof, a tool of cognitive activity in the investigation of criminal offenses. It is established that the legislative definition of investigative (investigative) action is imperfect and does not fully reflect its essence as a means of obtaining evidence during the pre-trial investigation. Scientific approaches to the definition of the main features and concepts of investigative (investigative) actions in the professional literature are analyzed and on their basis a more detailed interpretation of the term "investigative (investigative) action" is proposed. It is established that the main features of the investigative (search) action are a clear regulation of the grounds, procedure and its authorized subjects by the rules of criminal procedure legislation; focus on finding, obtaining and verifying evidence and information about them. Investigative (search) action is defined as a set of cognitive and search actions carried out by authorized subjects on the grounds and in the manner prescribed by the criminal procedure law, in order to form the evidence base.

Key words: investigative (investigative) action, covert investigative (investigative) action, pretrial investigation, criminal proceedings, criminal procedural legislation.

провадженні: автореф. дис. ... канд. юрид. наук: спец. 12.00.09. Харків, 2018. 19 с.

21. Аазарєв А.П. Механізм проведення слідчих (розшукових) дій у кримінальному провадженні: дис. ... канд. юрид. наук: 12.00.09. Харків, 2018. 231 с. 